\title{
PENGARUH KEPEMIMPINAN, KOMPETENSI DAN DISIPLIN KERJA TERHADAP KINERJA PEGAWAI PADA BADAN KEPEGAWAIAN DAN PENGEMBANGAN SUMBER DAYA MANUSIA DAERAH KABUPATEN KERINCI
}

\author{
Etra, S.Kom ${ }^{1}$, Dr. H. Elfiswandi, SE.,MM.,Ak.,CA ${ }^{2}$ \\ ${ }^{1}$ Fakultas Ekonomi dan Bisnis Universitas Putra Indonesia "YPTK" Padang \\ e-mail : etra05042@gmail.com \\ ${ }^{2}$ Fakultas Ekonomi dan Bisnis Universitas Putra Indonesia "YPTK" Padang \\ e-mail : elfiswandi@upiyptk.ac.id
}

\begin{abstract}
Human resources (HR) is one of the most important factors that cannot even be separated from an organization, both institutions and companies. The government in carrying out its duties and responsibilities are required to produce good performance. This study aims to determine the effect of leadership, competence and work discipline on employee performance. The sample used in this study as many as 95 respondents who are at BKPSDMD Kerinci. The analytical method used in this study is multiple linear regression analysis. The results of this study indicate that leadership influences and significantly affects employee performance, competence influences and significantly affects employee performance, work discipline has a significant effect on employee performance, leadership, competence and work discipline jointly influences and significantly affects the performance of Kerinci Regency BKPSDMD employees.
\end{abstract}

Keyword : Leadership, Competence, Discipline, Employee Performance

\begin{abstract}
ABSTRAK
Sumber daya manusia (SDM) adalah salah satu faktor yang sangat penting bahkan tidak dapat dilepaskan dari sebuah organisasi, baik institusi maupun perusahaan. Pemerintah dalam melaksanakan tugas dan tanggung jawabnya dituntut untuk menghasilkan kinerja yang baik. Penelitian ini bertujuan untuk mengetahui pengaruh kepemimpinan, kompetensi dan disiplin kerja terhadap kinerja pegawai. Sampel yang digunakan dalam penelitian ini sebanyak 95 orang responden yang berada pada BKPSDMD Kabupaten Kerinci. Metode analisis yang digunakan dalam penelitian ini adalah analisis regresi linier berganda. Hasil penelitian ini menunjukkan bahwa kepemimpinan berpengaruh dan signifikan terhadap kinerja pegawai, kompetensi berpengaruh dan signifikan terhadap kinerja pegawai, disiplin kerja berpengaruh signifikan terhadap kinerja pegawai, kepemimpinan, kompetensi dan disiplin kerja secara bersama-sama berpengaruh dan signifikan terhadap kinerja pegawai BKPSDMD Kabupaten Kerinci.
\end{abstract}

Kata Kunci : Kepemimpinan, Kompetensi, Disiplin Kerja, Kinerja Pegawai

(C) 2020 INFEB 


\section{PENDAHULUAN}

Sumber daya manusia (SDM) adalah salah satu faktor yang sangat penting bahkan tidak dapat dilepaskan dari sebuah organisasi, baik institusi maupun perusahaan. SDM juga merupakan kunci yang menentukan perkembangan perusahaan. Pada hakikatnya, SDM berupa manusia yang dipekerjakan di sebuah organisasi sebagai penggerak, pemikir dan perencana untuk mencapai tujuan organisasi itu.

Pemerintah dalam melaksanakan tugas dan tanggung jawabnya dituntut untuk menghasilkan kinerja yang baik. Kinerja pemerintah merupakan suatu hal yang penting, karena pemerintah merupakan aktor-aktor yang memiliki pengaruh besar terhadap kepentingan masyarakat. Baik atau buruknya kinerja pemerintah yang merasakan dampaknya adalah masyarakat, sehingga pemerintah diharapkan selalu meningkatkan kualitas baik kemampuan, keterampilan, kreativitas, keteladanan maupun profesionalisme (Hafid, 2018).

Prinsip otonomi daerah menggunakan prinsip otonomi seluas-luasnya dalam arti daerah di berikan kewenangan mengurus dan mengatur semua urusan pemerintahan sebagaimana diatur dalam Undang-undang Nomor 32 tahun 2004 tentang Pemerintahan, sebagaimana terakhir diubah dengan undang-undang nomor 12 Tahun 2008. Daerah memiliki kewenangan membuat kebijakan daerah untuk memberi pelayanan, peningkatan peran serta, prakarsa, dan pemberdayaan masyarakat yang bertujuan pada peningkatan kesejahteraan rakyat. Sejalan dengan prinsip tersebut dilaksanakan pula prinsip otonomi yang nyata dan bertanggung jawab.

Badan Kepegawaian Daerah (BKD) Kabupaten Kerinci mempunyai tugas pokok membantu kepala daerah dalam menyelenggrakan pemerintahan daerah di bidang manajemen kepegawaian daerah meliputi pengelolaan dan pembinaan kepegawaian daerah sesuai dengan kewenangan yang dimiliki daerah. Dalam melaksanakan tugas pokok tersebut BKD Kabupaten Kerinci mempunyai fungsi : 1) Perumusan kebijaksanaan tekhnis di bidang pengelolaan dan pembinaan kepegawaian daerah sesuai dengan kewenangan yang dimiliki oleh Daerah; 2) Pelayanan penunjang untuk kelancaran penyelenggaraan pemerintahan daerah di bidang pengelolaan dan pembinaan kepegawaian daerah yang meliputi perencanaan, pengadaan, pembinaan, pengembangan, pengendalian dan monitoring serta evaluasi pelaksanaan, pengelolaan dan pembinaan kepegawaian daerah; 3) Melakukan pelayanan teknis administrasi dan fungsional. Begitu banyaknya program dan kegiatan yang dilakukan oleh Badan Kepegawaian Daerah (BKD) Kabupaten Kerinci, maka dibutuhkan pegawai yang memiliki kinerja yang tinggi.

Menurut Mangkunegara (2016, hal. 67) kinerja ialah hasil kerja baik secara kualitas maupun kuantitas yang dicapai oleh seorang pegawai dalam melakukan tugas sesuai dengan tanggung jawab yang diberikan kepadanya. Kinerja adalah hasil dari suatu proses yang mengacu dan diukur selama periode waktu tertentu berdasarkan ketentuan atau kesepakatan yang telah di tetapkan sebelumnya (Edison 2016, hal. 190).

Kinerja pegawai yang baik akan secara langsung mempengaruhi kinerja organisasi, dan untuk itu perlu diberdayakan pola peningkatan kompetensi pegawai sehingga kinerja pegawai dapat dioptimalkan demi tercapainya tujuan dari organisasi. Hal ini menunjukkan bahwa kinerja pegawai dapat di bangun atau dipengaruhi oleh kompetensi yang dimiliki setiap pegawai. Semakin tinggi kompetensi yang dimiliki pegawai di sebuah organisasi, maka akan tercipta potensi yang luas bagi pegawai tersebut untuk dapat meningkatkan kinerjanya. Jadi secara eksplisit dapat dikatakan bahwa kompetensi pegawai berhubungan dengan kinerja (Hafid, 2018, hal. 288). 
Kompetensi adalah karakteristik dasar dari seseorang yang memungkinkan pegawai mengeluarkan kinerja superior dalam pekerjaannya. Berdasarkan uraian di atas makna kompetensi mengandung bagian kepribadian yang mendalam dan melekat pada seseorang dengan perilaku yang dapat diprediksi pada berbagai keadaan dan tugas pekerjaan. Prediksi siapa yang berkinerja baik dan kurang baik dapat diukur dari kriteria atau standar yang digunakan (Mogot, Kojo \& Lengkong, 2019, hal. 884).

Aspek lain yang mempengaruhi keberhasilan dari suatu organisasi ialah kepemimpinan. Tanpa kepemimpinan, aktivitas dalam suatu organisasi tidak akan teratur. Hal ini disebabkan karena setiap pemimpin dapat memberikan pengaruh terhadap bawahannya dalam menjalankan aktivitas-aktivitas organisasi. Pola perilaku seorang bawahan akan banyak diwarnai oleh perilaku atasannya sebagai pemimpin karena mereka selalu berinteraksi.

Disiplin kerja merupakan suatu sikap taat dan patuh serta tunduk pada aturan yang dilandasi oleh kesadaran dari diri pribadi tanpa ada paksaan dari luar. Sikap semacam ini tidak hanya dituntut dari pegawai sebagai individu, tetapi juga dari kelompok orang yang tergabung dalam organisasi tersebut. Dengan disiplin kerja pegawai dapat lebih bertanggung jawab terhadap tugasnya sehingga kinerjanya akan lebih baik, pegawai yang memiliki disiplin kerja akan memiliki kinerja yang lebih baik yang dapat membangun produktivitas pegawai tersebut disiplin kerja harus dibangun pada setiap pegawai mulai dari dini. Dengan adanya sumber daya yang baik, dan kedisiplinan kerja yang baik maka kompetensi yang baik akan tercipta, sehingga kinerja yang baik akan ikut serta dalam organisasi tersebut.

\section{METODOLOGI PENELITIAN}

\subsection{Objek Penelitian}

Tempat penelitian dilakukan di Badan Kepegawaian dan Pengembangan Sumber Daya Manusia Daerah Kabupaten Kerinci. Waktu penelitian akan dilaksanakan bulan Desember 2019, namun beberapa persiapan telah dilakukan sebelumnya. Hal ini didasarkan berbagai faktor untuk memperlancar pengumpulan data dalam penelitian, seperti kemudahan pengambalian data dan menghemat waktu serta tenaga yang digunakan.

\subsection{Variabel Operasional}

Pada penelitian ini penulis menggunakan tiga variabel yaitu:

- Variabel independen (bebas)

Variabel bebas adalah merupakan variabel yang mempengaruhi atau yang menjadi sebab perubahannya atau timbulnya variabel dependen atau terikat (Sugiyono, 2014, hal 59). Dalam penelitian ini yang menjadi variabel bebas (independent variable) adalah Kepemimpinan $\left(\mathrm{X}_{1}\right)$, Kompetensi $\left(\mathrm{X}_{2}\right)$, Disiplin Kerja $\left(\mathrm{X}_{3}\right)$.

- $\quad$ Variabel dependen (terikat)

Variabel terikat merupakan variabel yang dipengaruhi atau yang menjadi akibat, karena adanya variabel bebas (Sugiyono, 2014, hal 59). Dalam penelitian ini yang menjadi variabel terikat (dependent variable) adalah Kinerja Pegawai (Y).

\subsection{Analisis Regresi Linier Berganda}

Analisis regresi linier berganda digunakan untuk memprediksikan berubahnya nilai variabel tertentu bila variabel lain berubah. Menurut Sugiyono (2014, hal 277), dikatakan regresi berganda karena jumlah variabel independennya lebih dari satu. Analisis regresi berganda dapat dilakukan apabila terdapat minimal 2 variabel independen. Dalam pengujian hipotesis penelitian, digunakan uji regresi linier berganda.

Adapun tujuan menggunakan analisa regresi berganda dalam penelitian ini adalah untuk mengetahui bagaimana pengaruh variabel bebas disiplin kerja, empowerment 
dan kepuasan kerja secara simultan (bersama-sama) terhadap kinerja pegawai BKPSDMD Kabupaten Kerinci. Dengan demikian, dapat dikemukakan persamaan regresi linear berganda dalam penelitian ini adalah sebagai berikut :

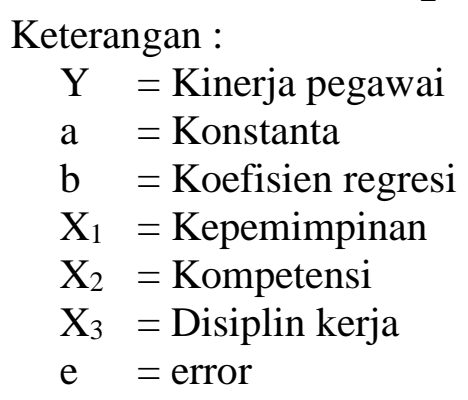

$$
\mathbf{Y}=\mathbf{a}+\mathbf{b}_{1} \mathbf{X}_{1}+\mathbf{b}_{2} \mathbf{X}_{2}+\mathbf{b}_{3} \mathbf{X}_{3}+e
$$

\section{Uji Parsial (Uji-t)}

Uji statistik t digunakan untuk menunjukkan seberapa jauh pengaruh satu variabel independen terhadap variabel dependen dengan menganggap variabel independen lainnya konstan (Ghozali, 2017, p. 96).

\section{Uji Simultan (Uji-F)}

Uji statistik F pada dasarnya menunjukkan apakah semua variabel independen yang dimasukkan dalam model mempunyai pengaruh secara bersama-sama atau simultan terhadap variabel dependen (Ghozali, 2017, p. 96).

\section{Uji Koefisien Determinasi (R-Square/ $\mathbf{R}^{2}$ )}

Koefisien determinasi $\left(\mathrm{R}^{2}\right)$ digunakan untuk mengukur seberapa jauh kemampuan model dalam menerangkan variasi variabel dependen. Nilai koefisien determinasi adalah antara nol dan satu. Nilai $\mathrm{R}^{2}$ yang kecil berarti kemampuan variabel independen dalam menjelaskan variabel dependen yang terbatas.

\section{III.HASIL DAN PEMBAHASAN}

Kuesioner disebarkan kepada pegawai Badan Kepegawaian dan Pengembangan Sumber Daya Manusia Daerah Kabupaten Kerinci sebanyak 95 buah dan semua kuesioner berhasil dikumpulkan kembali. Penyebaran kuesioner ini dilakukan dari tanggal 20 Januari 2020 sampai dengan 24 Januari 2020.

\section{Uji Normalitas}

Uji normalitas bertujuan untuk menguji bahwa distribusi sampel dari data mendekati normalitas populasi. Pengujian normalitas dilakukan dengan menggunakan analisa grafik histogram dan grafik p-plot. Data dapat dikatakan berdistribusi normal jika data menyebar disekitar garis diagonal dan mengikuti arah garis diagonal atau grafik histogramnya, sebaliknya data dikatakan tidak berdistribusi normal, jika data menyebar jauh dari arah garis atau tidak mengikuti diagonal atau grafik histogramnya. Hasil uji normalitas dapat dilihat pada gambar di bawah ini :

\section{Gambar 4.1 Grafik Histogram}




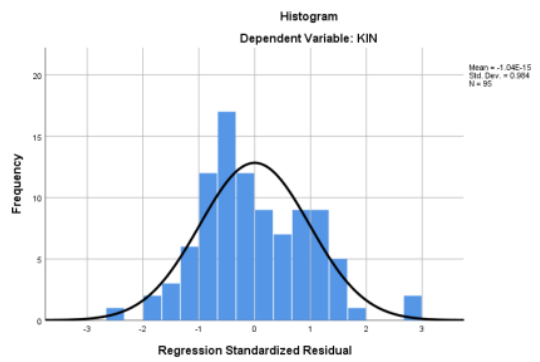

Sumber : Lampiran Print out SPSS

\section{Gambar 4.2 Grafik Normal P-P Plot}

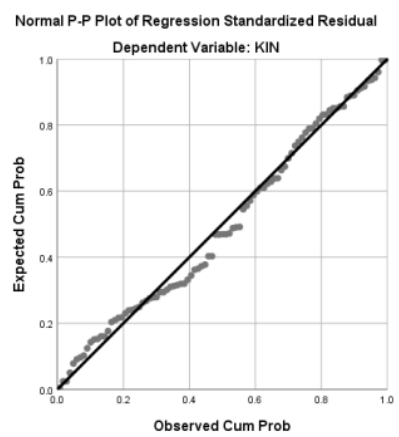

Sumber : Lampiran Print out SPSS

Berdasarkan gambar di atas dapat dilihat bahwa grafik histogram dan grafik p-plot memberikan pola distribusi yang bergerak ke arah kanan dan titik-titik menyebar mengikuti dan mendekati garis diagonal sehingga dapat disimpulkan bahwa model regresi memenuhi asumsi normalitas. Selain itu untuk menguji apakah data berdistribusi normal atau tidak maka dilakukan uji One-Sample Kolmogorov-Smirnov Test, data dikatakan normal apabila nilai Asymp.sig.(2tailed) nilainya lebih besar dari nilai signifikansi 0,05.

Tabel 4.1 Uji Normalitas

\begin{tabular}{llr}
\hline & & Unstandardized Residual \\
\hline $\mathrm{N}$ & & 95 \\
Normal Parameters ${ }^{\mathrm{a}, \mathrm{b}}$ & Mean & .0000000 \\
& Std. Deviation & 2.36440565 \\
Most Extreme Differences & Absolute & .077 \\
& Positive & .077 \\
& Negative & -.044 \\
Test Statistic & & .077 \\
Asymp. Sig. (2-tailed) & & $.200^{\mathrm{c}, \mathrm{d}}$ \\
\hline
\end{tabular}

Sumber : Lampiran Print out SPSS

Berdasarkan tabel di atas dapat diketahui bahwa nilai Asymp.Sig.(2-tailed) sebesar $0,200>0,05$. artinya data berdistribusi normal dan memenuhi uji asumsi klasik sehingga dapat dilanjutkan ke proses selanjutnya.

\section{Uji Multikolinearitas}

Salah satu syarat dalam pemakaian analisis regresi linier berganda adalah terlebih dahulu harus dilakukan uji multikolinieritas dimana sesama variabel bebas $\left(\mathrm{X}_{1}, \mathrm{X}_{2}\right.$ dan $\left.\mathrm{X}_{3}\right)$ tidak boleh berhubungan signifikan. Apabila sesama variabel bebas terdapat hubungan yang 
signifikan, maka salah satu variabel bebas tersebut tidak dimasukkan ke dalam regresi linier berganda.

\section{Tabel 4.2 Hasil Uji Multikolinearitas}

\begin{tabular}{clrr}
\cline { 2 - 3 } & \multicolumn{3}{c}{ Collinearity Statistics } \\
Todel & Tolerance & VIF \\
\hline 1 (Constant) & & \\
KEP & .589 & 1.698 \\
KOM & .204 & 4.904 \\
DIS & .252 & 3.961 \\
\cline { 2 - 3 } Sumber : Data diolah peneliti, 2020 &
\end{tabular}

Dari tabel di atas dapat diketahui nilai VIF 1,698 untuk $\mathrm{X}_{1}$ (kepemimpinan), nilai VIF 4,904 untuk $\mathrm{X}_{2}$ (kompetensi), dan nilai VIF 3,961 untuk $\mathrm{X}_{3}$ (disiplin kerja). Karena keseluruhan nilai lebih rendah dari 10 sehingga dapat disimpulkan tidak terjadi multikolinearitas, Dengan demikian semua variabel bebas yang diteliti dapat memenuhi syarat pemakaian model regresi berganda.

\section{Uji Heteroskedastisitas}

Hasil pengujian heteroskedastisitas untuk masing-masing variabel kepemimpinan, kompetensi, disiplin kerja dan kinerja pegawai dapat dilihat pada gambar di bawah ini :

\section{Gambar 4.3 Hasil Uji Heteroskedastisitas}

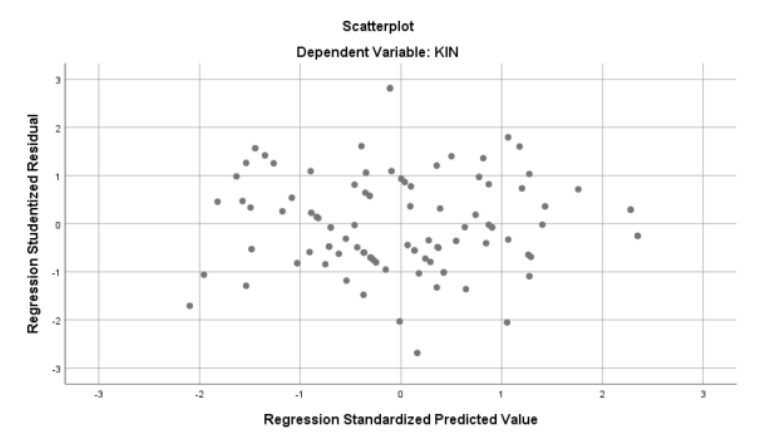

Sumber : Data diolah peneliti, 2020

Berdasarkan tampilan scatterplot, terlihat bahwa plot menyebar secara acak di atas maupun di bawah angka nol (0) pada sumbu regression studentized residual, maka dapat disimpulkan bahwa uji heteroskedastisitas menggunakan metode analisis grafik, pada model regresi yang terbentuk dinyatakan tidak terjadi heteroskedastisitas.

\section{Analisis Regresi Linier Berganda}

Analisis regresi linier berganda digunakan untuk memprediksikan berubahnya nilai variabel tertentu bila variabel lain berubah. Tujuan menggunakan regresi linier berganda adalah untuk mengetahui dan menjelaskan pengaruh kepemimpinan, kompetensi dan disiplin kerja secara bersama-sama terhadap kinerja pegawai. Persamaan analisis regresi linier berganda yang digunakan dalam penelitian ini adalah sebagai berikut :

Tabel 4.3 Hasil Regresi Linier Berganda

\begin{tabular}{cccc|c}
\hline \multicolumn{5}{c}{ Unstandardized Coefficients } \\
Model & B & Std. Error & t & Sig. \\
\hline 1 (Constant) & 6.248 & 3.171 & 1.970 & .052
\end{tabular}




\begin{tabular}{|c|c|c|}
\hline KEP & .361 & 000.072 5.006. \\
\hline KOM & -.261 & $\begin{array}{lll}.118 & -2.211 & .030\end{array}$ \\
\hline DIS & .785 & .000. 1037.592 \\
\hline
\end{tabular}

\section{Sumber : Data diolah peneliti, 2020}

Berdasarkan perhitungan diperoleh nilai koefisien regresi kepemimpinan $\left(\mathrm{X}_{1}\right)$ sebesar 0,361 , nilai koefisien regresi kompetensi $\left(\mathrm{X}_{2}\right)$ sebesar $-0,261$, nilai koefisien regresi disiplin kerja $\left(\mathrm{X}_{3}\right)$ sebesar 0,785 . Berdasarkan angka tersebut maka dapat disusun persamaan garis regresi sebagai berikut :

$$
\mathrm{KIN}=6,248+0,361 \mathrm{KEP}-0,261 \mathrm{KOM}+0,785 \mathrm{DIS}
$$

\section{Uji Parsial (Uji-t)}

Uji statistik t digunakan untuk menunjukkan seberapa jauh pengaruh satu variabel independen terhadap variabel dependen dengan menganggap variabel independen lainnya konstan. Berdasarkan tabel 4.3 diatas maka dapat ditarik kesimpulan bahwa :

1. Pengaruh kepemimpinan dengan nilai $\mathrm{t}$ hitung 5,006 lebih besar dari $\mathrm{t}$ tabel $(\mathrm{df}=\mathrm{n}-\mathrm{k}$ atau $\mathrm{df}=95-3=92$ nilai $\mathrm{t}$ tabel $=1,9852$ ). Dari nilai signifkansi, diperoleh nilai sebesar 0,000 sedangkan tingkat toleransi kesalahan yang digunakan adalah sebesar 5\%. Sehingga dapat disimpulkan bahwa nilai signifikansi kecil dari 0,05. Berarti keputusannya adalah Ho ditolak dan Ha diterima, yang artinya kepemimpinan berpengaruh dan signifikan terhadap kinerja pegawai pada Badan Kepegawaian dan Pengembangan Sumber Daya Manusia Daerah Kabupaten Kerinci.

2. Pengaruh kompetensi dengan nilai $\mathrm{t}$ hitung $-2,211$ lebih besar dari $\mathrm{t}$ tabel $(\mathrm{df}=\mathrm{n}-\mathrm{k}$ atau $\mathrm{df}=95-3=92$ nilai $\mathrm{t}$ tabel $=1,985)$. Dari nilai signifkansi, diperoleh nilai sebesar 0,030 sedangkan tingkat toleransi kesalahan yang digunakan adalah sebesar 5\%. Sehingga dapat disimpulkan bahwa nilai signifikansi kecil dari 0,05. Berarti keputusannya adalah Ho ditolak dan Ha diterima, yang artinya kompetensi berpengaruh dan signifikan terhadap kinerja pegawai pada Badan Kepegawaian dan Pengembangan Sumber Daya Manusia Daerah Kabupaten Kerinci.

3. Pengaruh disiplin kerja dengan nilai $t$ hitung 7,592 lebih besar dari $t$ tabel $(\mathrm{df}=\mathrm{n}-\mathrm{k}$ atau $\mathrm{df}=95-3=92$ nilai $\mathrm{t}$ tabel $=1,985)$. Dari nilai signifkansi, diperoleh nilai sebesar 0,000 sedangkan tingkat toleransi kesalahan yang digunakan adalah sebesar 5\%. Sehingga dapat disimpulkan bahwa nilai signifikansi kecil dari 0,05. Berarti keputusannya adalah Ho ditolak dan Ha diterima, yang artinya disiplin kerja berpengaruh dan signifikan terhadap kinerja pegawai pada Badan Kepegawaian dan Pengembangan Sumber Daya Manusia Daerah Kabupaten Kerinci.

\section{Uji Simultan (Uji-F)}

Untuk mendapatkan bukti empiris ada atau tidaknya pengaruh nyata antara variabel yang terdiri dari kepemimpinan, kompetensi dan disiplin kerja secara bersama-sama terhadap kinerja pegawai, maka dilakukan F-test. Berdasarkan hasil pengujian diperoleh ringkasan hasil seperti yang terlihat pada tabel di bawah ini :

Tabel 4.4 Hasil Uji Simultan

\begin{tabular}{lllll} 
Model Sum of Squares df & Mean Square & F & Sig. \\
\hline
\end{tabular}




\begin{tabular}{|c|c|c|}
\hline 1 Regression & 1315.7013 & $438.56775 .946 .000^{b}$ \\
\hline Residual & 525.49991 & 5.775 \\
\hline Total & 1841.20094 & \\
\hline
\end{tabular}

Dari hasil uji $\mathrm{F}_{\text {-hitung }}$ terhadap variabel kepemimpinan, kompetensi dan disiplin kerja dilakukan dengan program SPSS diperoleh nilai signifikan sebesar 0.000, sedangkan tingkat toleransi yang digunakan adalah sebesar 5\%. Atau dengan nilai $\mathrm{F}_{\text {-hitung }}$ sebesar 75,946 > $\mathrm{F}_{\text {-tabel }}$ sebesar 2,70 $(\mathrm{dF} 1=3 \mathrm{dF} 2=95-3-1=91)$. Sehingga dapat disimpulkan bahwa nilai signifikansi kecil dari 0,05. Berarti keputusannya adalah Ho ditolak dan Ha diterima, yang artinya variabel kepemimpinan, kompetensi dan disiplin kerja secara bersama-sama berpengaruh positif dan signifikan terhadap kinerja pegawai pada Badan Kepegawaian dan Pengembangan Sumber Daya Manusia Daerah Kabupaten Kerinci.

\section{Uji Koefisien Determinasi (R-Square)}

Berdasarkan hasil dari data yang telah diproses dapat dilihat kontribusi variabel kepemimpinan, kompetensi dan disiplin kerja terhadap kinerja pegawai. Berdasarkan hasil pengujian diperoleh ringkasan hasil seperti yang terlihat pada tabel di bawah ini :

Tabel 4.5 Hasil Uji Koefisien Determinasi

\begin{tabular}{lrrrrr}
\hline & & & \multicolumn{3}{c}{ Durbin-Watson } \\
Model & $\mathrm{R}$ & R Square & Adjusted R Square & Std. Error of the Estimate & \\
\hline 1 & $.845^{\mathrm{a}}$ & .715 & .705 & 2.403 & 2.157 \\
\hline
\end{tabular}

Sumber : Data diolah peneliti, 2020

Dari tabel di atas diketahui kepemimpinan, kompetensi dan disiplin kerja, terhadap kinerja pegawai dengan nilai korelasi sangat kuat terlihat dari nilai koefisien sebesar (R) 0,715 . Hasil adjusted $\mathrm{R}^{2}$ diperoleh nilai koefisien sebesar 0,705 atau $70,5 \%$. Artinya adalah kepemimpinan, kompetensi dan disiplin kerja proporsinya secara simultan menjelaskan pengaruh terhadap kinerja pegawai sebesar 70,5\%, sedangkan sisanya sebesar 29,5\%, dijelaskan oleh variabel lain yang tidak digunakan dalam penelitian ini.

\section{Pembahasan}

\section{Pengaruh Kepemimpinan terhadap Kinerja Pegawai}

Berdasarkan hasil analisis terdapat pengaruh dan signifikan antara kepemimpinan terhadap kinerja pegawai pada Badan Kepegawaian dan Pengembangan Sumber Daya Manusia Daerah Kabupaten Kerinci. Hal ini dibuktikan dengan nilai t hitung 5,006 lebih besar dari $t$ tabel $(5,006>1,985)$ dengan tingkat signifikan lebih kecil dari alpha $(0,000<0,05)$, maka Ho ditolak dan $\mathrm{H}_{\mathrm{a}}$ diterima. Artinya, secara parsial ada pengaruh dan signifikan antara kepemimpinan $\left(\mathrm{X}_{1}\right)$ terhadap kinerja pegawai $(\mathrm{Y})$. Nilai koefisien regresi variabel kepemimpinan bernilai positif sebesar 0,361. Artinya bahwa setiap peningkatan kepemimpinan sebesar 1 satuan maka kinerja pegawai akan meningkat sebesar 0,361 satuan dengan asumsi variabel lain nilainya konstan.

Tanpa kepemimpinan, aktivitas dalam suatu organisasi tidak akan teratur. Hal ini disebabkan karena setiap pemimpin dapat memberikan pengaruh terhadap bawahannya dalam menjalankan aktivitas-aktivitas organisasi. Pola perilaku seorang bawahan akan banyak di warnai oleh perilaku atasannya sebagai pemimpin karena mereka selalu berinteraksi.

Hasil penelitian ini sejalan dengan (Baskoro, Widowati \& Santoso, 2019), (Hafid, 2018), (Priyono, Qomariah \& Winahyu, 2018), (Almunawaroch, Suddin \& Lamidi, 2017) dan (Syafei, Fahmi \& Hubeis, 2016). Hasil penelitiannya diperoleh bahwa kepemimpinan 
berpengaruh dan signifikan baik secara parsial maupun secara simultan terhadap kinerja pegawai.

\section{Pengaruh Kompetensi terhadap Kinerja Pegawai}

Berdasarkan hasil analisis terdapat pengaruh dan signifikan antara kompetensi terhadap kinerja pegawai pada Badan Kepegawaian dan Pengembangan Sumber Daya Manusia Daerah Kabupaten Kerinci. Hal ini dibuktikan dengan nilai $t$ hitung -2,211 lebih besar dari $t_{\text {tabel }}(2,211>1,985)$ dengan tingkat signifikan lebih kecil dari alpha $(0,030<0,05)$, maka Ho ditolak dan $\mathrm{H}_{\mathrm{a}}$ diterima. Artinya, secara parsial ada pengaruh dan signifikan antara kompetensi $\left(\mathrm{X}_{2}\right)$ terhadap kinerja pegawai $(\mathrm{Y})$. Nilai koefisien regresi variabel kompetensi bernilai negatif sebesar 0,261. Artinya bahwa setiap peningkatan kompetensi sebesar 1 satuan maka kinerja pegawai akan menurun sebesar 0,261 satuan dengan asumsi variabel lain nilainya konstan.

Kompetensi adalah suatu kemampuan untuk melaksanakan suatu pekerjaan yang di landasi atas keterampilan dan pengetahuan serta di dukung oleh sikap kerja yang di tuntut oleh pekerjaan tersebut (Wibowo, 2016, hal 324). Kompetensi mengandung bagian kepribadian yang mendalam dan melekat pada seseorang dengan perilaku yang dapat di prediksikan pada berbagai keadaan dan tugas pekerjaan. Prediksi siapa yang berkinerja baik dan kurang baik dapat di ukur dari kriteria atau standar yang digunakan (Achmad, Umar \& Budiman, 2018).

Hasil penelitian ini sejalan dengan (Baskoro, Widowati \& Santoso, 2019), (Mogot, Kojo \& Lengkong, 2019), (Hafid, 2018). Hasil penelitiannya diperoleh bahwa kompetensi berpengaruh dan signifikan baik secara parsial maupun secara simultan terhadap kinerja pegawai.

\section{Pengaruh Disiplin Kerja terhadap Kinerja Pegawai}

Berdasarkan hasil analisis terdapat pengaruh dan signifikan antara disiplin kerja terhadap kinerja pegawai pada Badan Kepegawaian dan Pengembangan Sumber Daya Manusia Daerah Kabupaten Kerinci. Hal ini dibuktikan dengan nilai $t$ hitung 7,592 lebih besar dari $t$ tabel $(7,592>1,985)$ dengan tingkat signifikan lebih kecil dari alpha $(0,000<0,05)$, maka Ho ditolak dan $\mathrm{H}_{\mathrm{a}}$ diterima. Artinya, secara parsial ada pengaruh dan signifikan antara disiplin kerja $\left(\mathrm{X}_{3}\right)$ terhadap kinerja pegawai $(\mathrm{Y})$. Nilai koefisien regresi variabel disiplin kerja bernilai positif sebesar 0,785. Artinya bahwa setiap peningkatan disiplin kerja sebesar 1 satuan maka kinerja pegawai akan meningkat sebesar 0,785 satuan dengan asumsi variabel lain nilainya konstan.

Jadi kedisiplinan adalah kunci keberhasilan suatu perusahaan dalam mencapai tujuannya. Kesadaran di sini merupakan sikap seseorang yang secara sukarela menaati semua peraturan dan sadar akan tugas dan tanggung jawabnya. Jadi, dia akan mematuhi atau mengerjakan semua tugasnya dengan baik, bukan atas paksaan. Sedangkan kesediaan adalah suatu sikap, tingkah laku, dan perbuatan seseorang yang sesuai dengan peraturan instansi, baik yang tertulis maupun tidak tertulis

Hasil penelitian ini sejalan dengan (Mogot, Kojo \& Lengkong, 2019), (Hafid, 2018), (Almunawaroch, Suddin \& Lamidi, 2017). Hasil penelitiannya diperoleh bahwa disiplin kerja berpengaruh dan signifikan baik secara parsial maupun secara simultan terhadap kinerja pegawai.

\section{Pengaruh Kepemimpinan, Kompetensi dan Disiplin Kerja terhadap Kinerja Pegawai}

Berdasarkan hasil analisis dan uji hipotesis nilai $\mathrm{F}_{\text {-hitung }}$ sebesar 75,946 $>\mathrm{F}_{\text {-tabel }}$ sebesar 2,70, signifikansi probability $0,000<0,05$. Sehingga dapat disimpulkan bahwa nilai signifikansi kecil dari 0,05, artinya signifikan, ini berarti kepemimpinan, kompetensi dan disiplin kerja secara bersama-sama berpengaruh dan signifikan terhadap kinerja pegawai. 
Kontribusi kepemimpinan, kompetensi dan disiplin kerja terhadap kinerja pegawai sebesar $70,5 \%$ sedangkan sisanya $29,5 \%$ ditentukan oleh faktor lain. Faktor-faktor lain itu bisa berupa komitmen organisasi, pemberdayaan, kepuasan kerja, pelatihan pegawai, pengembangan karier, kompetensi, budaya organisasi, gaya kepemimpinan, kompensasi dan lain sebagainya.

Jadi dapat disimpulkan bahwa kepemimpinan, kompetensi dan disiplin kerja yang baik dapat meningkatkan kinerja pegawai pada Badan Kepegawaian dan Pengembangan Sumber Daya Manusia Daerah Kabupaten Kerinci. Selain itu nilai konstanta yang didapat dari hasil analisis regresi linier berganda adalah 6,248, artinya jika segala sesuatu yang ada pada variabel-variabel independen dianggap konstan maka nilai dari kinerja pegawai adalah 6,248. Hasil penelitian ini sejalan dengan (Baskoro, Widowati \& Santoso, 2019), (Mogot, Kojo \& Lengkong, 2019), (Hafid, 2018), (Almunawaroch, Suddin \& Lamidi, 2017). Hasil penelitiannya diperoleh bahwa kepemimpinan, kompetensi dan disiplin kerja secara bersamasama berpengaruh dan signifikan terhadap kinerja pegawai.

\section{IV.KESIMPULAN}

Hasil penelitian ini menunjukkan bahwa kepemimpinan berpengaruh dan signifikan terhadap kinerja pegawai, kompetensi berpengaruh dan signifikan terhadap kinerja pegawai, disiplin kerja berpengaruh signifikan terhadap kinerja pegawai, kepemimpinan, kompetensi dan disiplin kerja secara bersama-sama berpengaruh dan signifikan terhadap kinerja pegawai BKPSDMD Kabupaten Kerinci.

\section{UCAPAN TERIMAKASIH}

Terima kasih kepada Universitas Putra Indonesia "YPTK" Padang yang telah memberikan kesempatan penulis untuk menyelesaiakan jurnal ini dan LPPM STIA Nusantara Sakti Sungai Penuh yang telah memberi kesempatan untuk publish jurnal di OJS Jurnal Administrasi Nusantara (JAN). Sertasemua pihak yang tidak bisa disebutkan satu persatu dalam jurnal ini.

\section{VI.DAFTAR PUSTAKA}

Achmad., Umar, A., \& Budiman. (2018). Pengaruh Motivasi Kerja dan Kompetensi terhadap Kinerja Pegawai melalui Disiplin Kerja. Jurnal Mirai Management, Vol 3 (2), 92-119.

Ardana, K., Mujiati, N.W., \& Sriathi, A.A. (2009). Perilaku Organisasi. Yogyakarta: Graha Ilmu.

Aji, S.W., Suddin, A., \& Suseno, Y.D. (2017). Analisis Pengaruh Kepemimpinan dan Kompetensi terhadap Kinerja melalui Kompensasi sebagai Variabel Intervening (Survei pada Karyawan PT Wahana Sun Solo). Jurnal Manajemen Sumber Daya Manusia, Vol 11 (2), 306-316.

Almatrooshi, B., Singh, S.K., \& Farouk, S. (2016). Determinants of Performance: a Proposed Framework. International Journal Performance Management, Vol 65 (6), 844- 859.

Organizational
of Productivity and 
Almunawaroch, S., Suddin, A., \& Lamidi. (2017). Pengaruh Kompensasi, Kepemimpinan, Kompetensi dan Disiplin Kerja terhadap Kinerja Pegawai (Survei Pegawai Rumah Sakit Islam Amal Sehat Sragen). Jurnal Ekonomi dan Kewirausahaan, Vol 17 (1), 10-22.

Baskoro, A.L., Widowati, S.Y., Santoso, A. (2019). Menakar Determinan Kinerja Karyawan. Jurnal Manajemen Bisnis dan Inovasi, Vol 6 (1), 41-50.

Bella, M.J., \& Maichal. (2018). Pengaruh Mindset, Kepemimpinan dan Nilai Keluarga terhadap Budaya Organisasi Perusahaan Keluarga. DeReMa Jurnal Manajemen, Vol 13 (1), 121-139.

Bernardin, H.J., \& Russel, J.E.A. (2013). Human Resource Management an Experiental Approach. Singapore: McGraw Hill.

Chen, M.J., \& Miller, D. (2011). The Relational Perspective as a Business Mindset: Managerial Implication for East and West. The Academy of Management Perspective, Vol 23 (3), 6-18.

Edison. (2016). Manajemen Sumber Daya Manusia. Bandung: Alfabeta.

Effendi, U. (2011). Asas Manajemen. Jakarta: PT. Raja Grafindo.

Ghozali, I. (2017). Aplikasi Analisis Multivariete dengan Program IBM SPSS 23 (Edisi Ke-8). Semarang: Badan Penerbit Universitas Diponegoro.

Hafid, H. (2018). Pengaruh Kompetensi, Kepemimpinan dan Disiplin Kerja terhadap Kinerja Pegawai pada Samsat Polewali Mandar. DeReMa Jurnal Manajemen, Vol 13 (2), 286-310.

Hasibuan, M. (2016). Manajemen Sumber Daya Manusia. Jakarta: Bumi Aksara.

Hutapea, P., Thoha, N. (2008). Kompetensi Plus: Teori, Desain, Kasus dan Penerapan untuk HR dan Organisasi yang Dinamis. Jakarta: Gramedia Pustaka Utama.

Hutton, D.M. (2016). Critical Factors Explaining the Leadership Performance of HighPerforming Principals. International Journal of Leadership in Education, Vol 21 (2), 245-265.

Irawan, P. (2007). Manajemen Sumber Daya Manusia. Jakarta: STIA-LAN Press.

Mangkunegara. (2016). Manajemen Sumber Daya Manusia. Bandung: PT Remaja Rosdakarya.

Mathis, L., \& Jackson, J. (2011). Human Resource Management. Jakarta: Salemba Empat.

Men, L.R., \& Stack, D.W. (2013). The Impact of Leadership Style and Employee Empowerment on Perceived Organizational Reputation. Journal of Communication Management, Vol 17 (2), 171-192.

Moeheriono. (2012). Pengukuran Kinerja Berbasis Kompetensi. Jakarta: PT Raja Grafindo Persada.

Mogot, H.Y., Kojo, C., \& Lengkong, VPK. (2019). Pengaruh Gaya Kepemimpinan, Etos Kerja, Kompetensi dan Disiplin Kerja terhadap Kinerja Karyawan pada PT PLN Cabang Manado. Jurnal EMBA, Vol 7 (1), 881-890.

Prawirosentono. (2012). Manajemen Sumber Daya Manusia. Jakarta: Bumi $\quad$ Aksara.

Priyono, B.H., Qomariah, N., \& Ninahyu, P. (2018). Pengaruh Gaya Kepemimpinan, Motivasi Guru dan Lingkungan Kerja Fisik terhadap Kinerja Guru SMAN 1 Tanggul Jember. Jurnal Manajemen dan Bisnis Indonesia, Vol 4 (2), 144-160.

Rivai, V. (2013). Manajemen Sumber Daya Manusia untuk Perusahaan: Dari Teori ke Praktik. Jakarta: Raja Grafindo Persada. 
Ruky, A.S. (2014). Sistem Manajemen Kinerja. Jakarta: PT Gramedia Pustaka Utama.

Robbin, S. P., \& Coulter, M. (2015).. Perilaku Organisasi. (B. Molan, Trans.) Jakarta: Salemba Empat.

Sedarmayanti. (2012). Sumber Daya Manusia dan Produktivitas Kerja. Bandung: Mandar Maju.

Sinambela, L. P. (2012). Kinerja Pegawai; Teori Pengukuran dan Implikasi. Yogyakarta: Graha Ilmu.

Sugiyono. (2014). Metode Penelitian Kuantitatif dan R\&D. Bandung: Alfabeta.

Suliyanto. (2011). Ekonometrika Terapan: Teori dan Aplikasi dengan SPSS. Yogyakarta: Penerbit Andi.

Sutrisno. (2016). Manajemen Sumber Daya Manusia. Jakarta: Pranada Media Group.

Syafei, M., Fahmi, I., \& Hubeis, A.V.S. (2016). Faktor-Faktor yang Mempengaruhi Kinerja Karyawan PT Pul Logistics Indonesia. Jurnal Aplikasi Bisnis dan Manajemen, Vol 2 (3), 217-229.

Wibowo. (2016). Manajemen Kinerja. Jakarta: PT Raja Grafindo Persada. 